5. Krämer J, Owczarek V, Bickert U (1996) Lumbale epidurale Injektionen zur orthopädischen Schmerztherapie. Z Orthop 134: 12

6. Krämer J, Laubenthal H (1993) Spezielle Probleme der postoperativen Schmerzbehandlung in der Orthopädie. Anästhesiol Intensivmed 34: 401
7. Orthopädie Memorandum (1995) Storck-Verlag, Bruchsal

8. Schmidt RR, Thewes G (1987) Physiologie des Menschen. Springer, Berlin Heidelberg New York

9. Zenz M, Jurna J (1993) Lehrbuch der Schmerztherapie. Wissenschaftliche Verlagsgesellschaft, Stuttgart
10. Zimmermann M, Handwerker HD (1984) Schmerzkonzepte und ärztliches Handeln. Springer, Berlin Heidelberg New York

I.Jurna

\title{
Opioids in chronic pain therapy
}

In the last issue of "Der Schmerz" I. Jurna has presented a paper on "Opioids in chronic pain therapy" (Der Schmerz (1996) 10: 211-214). By mistake the following paragraph was ommitted:

\section{Results of a Sertuerner Workshop held on May, 4.-6. 1995 in Castrop-Rauxel Sertuerner Society Einbeck}

The Sertuerner Society organises 2 workshops every year on actual topics from the field of pain and anaesthesia. The 1995 spring-conference was headed "Opioids in chronic pain therapy". 30 colleagues from german speaking countries discussed a number of aspects of opioid therapy from neurobiology to clinical practice and concluded to a consensus paper. The results of this Sertuerner Workshop have been presented in german elsewhere [1]. The following english abstracts have been written and collected to further distribute the results obtained also for our english speeking colleagues.

\section{Reference}

1. Willweber-Strumpf A, Zenz M, Tryba M (1995) Leitlinien zur Therapie chronischer Schmerzen mit Opioiden. Ergebnisse des Sertürner Workshops „Chronische Opioidtherapie“. Anästhesist 44: 719 